\title{
HISTORICAL MEMORY IN PRESERVING ETHNO-RELIGIOUS IDENTITY: FOREIGN EXPERIENCE IN MANAGING MIGRATION AND CULTURAL SECURITY
}

\author{
Konstantin V. Vodenko ${ }^{1 *}$, Olga S. Ivanchenko ${ }^{2}$, Olesya E. Labadze ${ }^{3}$, Maria P. Tikhonovskova ${ }^{4}$ \\ ${ }^{1 *, 2,3,4}$ Platov South-Russian State Polytechnic University (NPI), Department of Personnel Management, Novocherkassk, \\ Russia.
}

Email: ${ }^{1 *}$ vodenkok@mail.ru, ${ }^{2}$ olga.ivanchenko1509@mail.ru, ${ }^{3}$ efimowa.olesya@yandex.ru, ${ }^{4}$ tihonovskovas@yandwx.ru Article History: Received on $23^{\text {rd }}$ March 2020, Revised on $24^{\text {th }}$ May 2020, Published on $21^{\text {st }}$ June 2020

\begin{abstract}
Purpose: The object of this paper is to develop the concept of historical memory as a resource for preserving the ethnoreligious identity and cultural security.

Design/methodology/approach: The methodological apparatus of research is based on civilizational and constructivist approaches that allow us to understand the specifics and role of identity in the modern world, as well as the concept of civilizational confrontation in modern migration processes. As a part of the study, we used the concept of "cultural trauma" to understand the influence of historical events on modern relations between Muslims and Europeans.

Result: It was found that the low level of Muslim migrants' integration into Western society is determined by socialpsychological and cultural-historical factors. The social-psychological factor is associated with an individual's need for group identity, which creates a zone of comfort and security. Muslim migrants' integration into European society is difficult because their ethnoreligious identity is exacerbated in conditions of migration. The cultural-historical factor is associated with discrepancies in civilizational models (Islamic and Western), the relations between them being conflictridden for a long period of time.
\end{abstract}

Application: This suggests that historical memory has a significant impact on the relations of modern Islamic and European cultures. Historical memory, preserving the plots of eternal rivalry and confrontation of Islamic and Western civilizations, affects the process of their rapprochement: firstly because the injuries of past are very difficult to get rid of; secondly, memory, as a collective past or as knowledge of this past, is the basis of social identity.

Originality/value: The study proves that the negative stereotypes prevailing in people's historical memory determine their perception of the present and the future. Consolidation of the "image of the enemy" in historical memory promotes the spread of Islamophobia in European society and radical Islamism in the Muslim world. The anti-Western ideology of radical Islamism undermines the historically present process of cultural interaction in the development of Western and Islamic civilizations.

Keywords: Historical Memory, Ethnoreligious Identity, Migration, Migration Crisis, Multiculturalism, Cultural Trauma, Conflict of Civilizations, Cultural Security.

\section{INTRODUCTION}

The relevance of historical memory problem and its role in maintaining the ethnoreligious identity of Muslim migrants is due to their unprecedented influx into Europe. As a result, many European states faced the migration crisis challenge, manifested in growth of social tension, ethnic and religious conflicts, the unwillingness of migrants, especially of Muslims, to incorporate into European society, accept its cultural norms and laws.

The active migration process has seriously transformed the cultural composition of Western societies, turning them into multi-cultural and multi-religious entities (Faleeva et al., 2017; Minakhmetova et al., 2017). A high percentage of immigrants of different ethnic and cultural identities contributed to some serious social problems, not only for the local population but for the migrants themselves (Makarova et al., 2019). One of these problems was the integration of migrants into different cultural and political spaces.

The working hypothesis of this study is that historical memory of long-standing confrontation between Islamic and Western civilizations is one of the factors determining the unwillingness of Muslim migrants to incorporate into Western society. The coding of social experience about the tragic events associated with the history of Crusades and European colonization of Muslim peoples is an obstacle to the integration of Muslims into the cultural and political space of European states.

The prevailing negative stereotypes in people's historical memory, which determine their understanding of the present and the future, have not been studied in previous studies. Thus, this work aims to substantiate the role of historical memory in maintaining the ethno-religious identity of Muslims in the context of their migration to European countries.

\section{LITERATURE REVIEW}

The conceptual basis for the study of historical memory is established in the writings of C. Jung (2012), E. Durkheim (1976), M. Halbwachs (1950), and Assmann, J. (2011). The chronicled calling, the broad communications, and even the 
scholarly network to improve the open's recognition with the previous, a fundamental part of enthusiasm were examined (Zh.T. Toshchenko. 2000). Theoretical aspects of identity problems are studied (H. Tajfel and J.C, Turner. 1986).

An orderly, hypothetical treatise in the humanism of information was introduced. Plus, basic remarks on other hypothetical positions have been acquainted with explaining the contention (Berger, P. L., \&Luckmann, T. 1991). Huntington (2000) battles that socially-based "civic establishments" apply more grounded hangs on individuals than financial frameworks, levels of advancement, or even political frameworks.

Historical and modern aspects of civilizational contradictions are studied in the works of such scientists as $\underline{B}$. Lewis $\underline{(1993)}$ and J. Esposito (1999). The situation of present-day Islamists is that "Western and Muslim civic establishments are totally contradictory. The battle against Western impact for Islamic "legitimacy" and "particularity" is, as they would see it, a fight for the protection of Muslim character, Muslim culture, Muslim progress" (V.I. Komar. 2004).

The specific features of the current migration crisis in European countries are discussed (R. Leiken .2005, O. Rua. 2017). Researchers express, that "by the endeavors of the United States globalization is abandoning deliberate incorporation or equivalent and sovereign expresses that safeguard their character and national customs into one - the most aspiring, arranged and continually arranged in detail, oversaw in the primary parts of geopolitical activity of the Western world, pointed not exactly at vanquishing the world administration, control, and the authority of the transformative procedure of humankind and its administration to their greatest advantage" (Z.I. Levin. 2017).

The tranquil result of the 2015 general decisions that were proof of amicable relationship among ethnic gatherings and religion that added to the development of majority rule government in Nigeria was broke down (Bekuma, G. B., \&Bogoro, A. E. 2017). Alevism must be viewed as an ethnic-strict character which is framed under various social conditions and developed through the complexities of the association of ocaks in a tremendous domain enveloping distinctive ethnic gatherings (Aydın, S. 2018). The association between pilgrim managerial approaches, urban arranging techniques, and contemporary clashes in an African city was grilled (Nnabuihe, O. E., \&Onwuzuruigbo, I. 2020).

At the same time, even though much attention is paid to the topic in scientific discourse, there is no comprehensive analysis related to the study of historical memory influence on the preservation of the ethno-religious identity of Muslims in European countries. This subject requires further systematic research in the field of identifying the potential of historical memory in modern migration processes.

\section{METHODOLOGY}

The methodological apparatus of research is based on a civilizational approach, which allows us to understand the causes of conflicts of various civilizational systems, both in historical and in modern contexts (Cherdymova et al., 2018). This approach explains civilizational conflicts in modern migration processes as well.

This research is based on the constructivist approach to identity, which forms in the process of constructing social boundaries that differentiate communities by cultural markers. Besides, the constructivist approach allows us to treat ethno-religious identity as a construction that is created by people in the course of historical development.

The theoretical basis of the study is the concept of "cultural trauma", which allows understanding the influence of historical events on modern relations between Muslims and Europeans.

The need for overcoming negative stereotypes that remain in the fold of people's historical memory preventing the convergence of the Islamic world and the West is substantiated at the end of the paper

\section{RESULTS}

\section{Migration Crisis in Europe and the Problem of Integration of Muslim Migrants}

Currently, an extremely difficult problem has reared its head. It is caused not only by the world migration flows increase, but by their orientation (mainly to Western countries) as well. Obviously, the unfavorable economic situation prevailing in many regions is the main cause of modern mass migration. For many people in a ruined economy of some countries, migration is the only way to survive.

Previously, in the political practice of Western countries, the problem of foreign cultural migrants' integration was solved through assimilation and multicultural models of managing ethnic and religious differences. But the current situation in many European countries testifies to their inefficiency.

Experts state, that "... the simulation model failed because it initially ignored religious dimension of immigrant identity and assumed that this dimension would gradually fade away in the process of integration" (Rua, 2017, 79). However, the rise in various forms of Islamic revival among integrated immigrants indicates the need to find a new model of multiconfessional society management.

The model of multiculturalism also failed. It was oriented towards recognition of cultural differences and their preservation, the main goal being migrant integration based on national-civic identity formation. One of the requirements was "the loyalty of migrants to the national-state integrity of the host country. On the one hand, migrants must show 
commitment to the new society, study its history, language, and traditions. On the other hand, the host society must show its disposition to new citizens and change, adapting the institutions to new identities and sociocultural practices" (Shchedrina, 2004, 70-71). But in developed countries today's immigrants have no desire to integrate into the legal space of the host society, even preserving their cultural differences. So the host population has no desire to be tolerant of the migrants. Besides, multiculturalism policy did not take into account the religious factor, which is built into the culture and determines the worldview of the population. In the twentieth century, with the revival of Islam and its role in modern geopolitical processes, the implementation of the multiculturalism model does not contribute to the integration of Muslims into European society, but rather creates conditions for them to preserve their cultural identity as opposed to the values of the Western world.

The analysis of the current situation in many developed countries shows that "the recent history of immigrant communities in European and North American recipient states indicates their desire for autarchy... In extreme cases, it splashes out in various aggressive forms of ethnocentrism and intolerance manifestation, in an effort to impose its ethnocultural attributes and stereotypes on the host majority" (Yakimova, 2011, 53-54).

The presence of Muslim immigrants is fundamentally changing (formerly) culturally homogeneous nations of Europe. The ideology and politics of European states have led them to become a refuge "for Muslims who are dissatisfied with life and who do not fit into their culture or social environment" (Leiken, 2005, 93).

On this basis, it can be claimed that the growth of social ethnocultural diversity leads to the emergence of new civilizational social faults. Moreover, this fault goes through the territory of European states, which are seriously puzzled by the problem of ensuring their national security.

\section{Historical Memory as a Factor in Preserving the Ethno-Religious Identity of Muslim Migrants}

The low level of integration of Muslim migrants into Western society can be explained by both social-psychological and cultural-historical factors.

The socio-psychological factor is associated with the individual's need for group identity to create a zone of comfort and security. Since migration is associated with getting into a different cultural space, it is naturally accompanied by disorientation: migrants search for a place that gives a feeling of certainty and stability. In this regard, the ethno-religious identity of Muslim migrants is the primary social resource that fixes the boundaries of their local world and allows them to adapt to foreign cultures. Therefore, the resettlement of Islam adherents to Western countries is often not accompanied by integration desire - on the contrary, it exacerbates the feeling of their own ethno-religious identity, embodying comfortable and apprehensible cultural environment.

Along with social-psychological reasons, the false adaptation of Muslim migrants to Western society is determined by cultural and historical factors associated with various civilization models (Western and Eastern). For a long period of time, their relations were mostly conflicting. In the modern interaction of the Islamic and Western world, according to $\underline{S}$. Huntington (2000), there lies the conflict of civilizations, which originates from the era of Crusades and European colonialism.

In this aspect, it can be considered that the historical memory of Crusades and colonization of the eastern territories by the West has a significant impact on modern relations between Islam and European society.

In scientific discourse, there is no unified approach to the understanding of historical memory. In scientific literature, the concepts of "social memory", "collective memory" and "cultural memory" are used along with the concept of "historical memory".

In his works, E. Durkheim (1976) used the term "social memory" to describe conditions of memorial socialization of social members, preservation of collective identity, and maintenance of social organism existence in and of itself (Durkheim, 1976, 153). Thus, according to the scientist, social memory acts as the basis for the consolidation and translation of collective identity. The symbols of community identity are preserved through social memory.

The term "collective memory" appears in the works of M. Halbwachs (1950) (sociologist, France). According to his approach, memory can only be collective, since individual impressions are woven into the social context and preserved only through the process of an individual's socialization (Halbwachs, 1950). Analyzing the nature of collective memory, the researcher identifies the following structure in it: 1) the Spatio-temporal correlation that determines geographical and historical coordinates of social events; 2) social conditioning, that allows communities to operate on their own criteria to form the image of the past; 3 ) a recreative character associated with the interpretation of facts only within the framework of generally accepted scenario, which is focused on interests of the social groups.

According to M. Halbwachs (1950), the main features of collective memory are originality and durability. The originality of collective memory is one of the markers for identifying a cultural community: collective memory affirms and supports the community's cultural differentiation.

The concept of cultural memory is developed by the German culturologist Assmann, J. (2011), who treats this type of memory as "a special symbolic form of transmission and actualization of cultural meanings that goes beyond the 
experience of individual people or groups (Assmann, J. 2011). As a certain level of collective memory, cultural memory is a set of signs, figurative, and verbal representations of the past. According to the scientist, translation of cultural memory is carried out through the main social institutions - family, education, media, and the state.

The central component of historical memory is the image of the past, which forms the basis of a particular culture's worldview. Moreover, this image incorporates both scientific and unscientific information. $\underline{\text { C. Jung (2012) also paid }}$ attention to the role of the unconscious in the culture of society, arguing that the property of memory is its ability to reproduce unconscious contents and to communicate with things that have become subconscious - suppressed or discarded. (Jung, 2012, 67). According to this approach, the archetypes of cultural memory are transmitted from generation to generation exclusively through mythological images, religious systems, and traditions, which make up the worldview core of any culture.

Historical memory as one of the most important identification mechanisms is studied in the works of V.E. Boykov (2011), K.S. Romanova (2016), Zh.T. Toshchenko (2000) and others. Treating historical memory as a system of value orientations, the authors emphasize its influence on the formation of the ethno-religious identity of individuals and, accordingly, on the forms of their social behavior.

According to V.E. Boykov (2011), the system of historical memory includes the following elements: a) a set of generally valid values; b) understanding of one's "Me" in family and generation history, an awareness of one's cultural identity in the system of world civilization; c) historical traditions, ideals, beliefs, transmitted from generation to generation and forming the worldview and mentality of the people.

Thus, historical memory as a mechanism for preserving cultural identity reproduces the continuity of social being. In this aspect, as researchers note, "it is historical memory that ensures that people realize that they are not a crowd, but are united in a social community, into a people with a specific culture, language, mental qualities" (Boykov, 2011, 47).

\section{Cultural Trauma as a Component of Historical Memory}

At the same time, researchers pay attention to the fact that historical memory is a kind of "repository" - not only of some bright heroic events and victories but also of dramatic pages in the history of peoples.

In this regard, in the field of social knowledge, a cultural trauma discourse has developed. The beginning of this discourse dates back to the works of C. Caruth (1995), R. Eyerman (2004), J. Alexander (2004), and P. Sztompka (2001). According to the authors, events that leave unhealed wounds in the history of a society can be attributed to the category of cultural trauma. Besides, cultural trauma is collective, because, according to P. Sztompka (2001), it represents "a condition experienced by a group, community, society as a result of destructive events interpreted as cultural and traumatic" (Sztompka, 2001, 12). This position is shared by J. Alexander (2004), who emphasizes that an event becomes socially traumatic if it poses a threat to collective identity.

The use of a trauma paradigm in the study of historical memory role in reproducing the ethno-religious identity of Muslim migrants in Western countries allows us to understand social-psychological and cultural-historical factors that affect the difficulties of their assimilation process in the host society.

One of the main plots of Muslim historical memory is colonization by the West. The famous British historian B. Lewis (1993) notes that "the entire complex process of European expansion and imperialism in the last five centuries has its roots in the clash between Islam and the Christian world" (Lewis, 1993, 17).

We can agree that the relations between Muslims and Christians are burdened by the memory of Crusades, and, of course, first of all, European colonization, which is not such a distant past. During the Crusades Europeans stopped, reaching the Holy Land, and did not plan to go beyond the Middle East, but in the $19^{\text {th }}$ and $20^{\text {th }}$ centuries, having a true military-technical advantage, they captured all of Asia and Africa. The result was a European colonial system: the Spanish and French colonies were in America and South Africa; Dutch colonies appeared in the East Indies (Indonesia); Portuguese - in Brazil, the West Indies, and China (Macau).

Modernized Europe needed resources, and it sought to withdraw them from the eastern regions, legitimizing this with the idea of developing backward peoples, bringing them to achievements of the Western world. But European expansion turned out to be quite painful for Muslims. Even though Western colonialism was not directed against Islam as during the Crusades, pursuing exclusively economic goals, this was a serious trauma for Muslims.

Scientists' state, that this situation was perceived by Muslims as an extremely painful one: "the happy days of Islam passed and the time of submission came, and this was a terrible blow for Muslims, which led not only to a crisis in economic and political life but also to religious and psychological upheavals. For the first time in their long history, infidels ruled them" (Amur, 2004, 214).

Assessing the impact of European colonization on modern relations between Islam and the Western world, the American historian, Islamic scholar J. Esposito (1999), believes that "in the first half of the twentieth century, two problems prevailed in Muslim history: European imperialism and the struggle for independence from the colonial power. Few 
events have had more serious consequences on Islamic relations with the West than European colonization" (Esposito, 1999, 45).

\section{Features of the Modern Confrontation between Islamic and Western Civilizations}

Modern processes taking place in the world testify to the revival of civilizational confrontation, dictated by globalization, which is often regarded as the process of Western neo-colonization of the rest of the world. Scientists state, that "by the efforts of the United States globalization is turning from voluntary integration of equal and sovereign states that preserve their identity and national traditions into one - the most ambitious, planned and constantly planned in detail, managed in the main aspects of the geopolitical operation of the Western world, aimed not just at conquering the world leadership, domination, and the mastery of the evolutionary process of mankind and its management in their interests" (Levin, 2017, 169-174). In this regard, the process of globalization is identified with a new stage of Western expansion aimed at establishing global economic, political, and cultural control over the rest of the world.

Today, adherents of Islam see the West as a threat again, not only territorial but spiritual. The leaders of the Islamic world accuse the West of destroying "the specifics of the Arab-Muslim civilization by imposing alien models of cultural, economic, and political development on it. It is the West and Western influence that are declared the main cause of stagnation and crisis in the Muslim world" (Komar, 2004, 9). It is obvious that the reluctance of Muslims to accept Western norms and values, even on the territory of European countries, is due to the historical memory of the eternal confrontation of two civilizations.

In the current geopolitical confrontation, historical memory is often used as a political tool for integration and mobilization of Muslims to fight against the West. The politicization of historical memory of Muslims, in which ideas about eternal inter-civilizational confrontation are used, leads to the appearance of radical movements in Islam. The position of modern Islamists is that "Western and Muslim civilizations are completely incompatible. The struggle against Western influence for Islamic "authenticity" and "specificity" is, in their opinion, a battle for the preservation of Muslim identity, Muslim culture, Muslim civilization" (Komar, 2004, 11). Thus, the current revival of Islam in its radical forms can be seen as a reaction of the Muslim world to the expansion of the West.

\section{DISCUSSION}

Scientific discourse has developed an ambiguous attitude towards the civilizational paradigm. Some scientists believe that the concept of "clash of civilizations" by $\underline{S}$. Huntington (2000) greatly simplifies the complexity of conflicts in the modern world. But some critics state, that "the idea of civilizational conflicts" does not reflect all the causes of today's geopolitical confrontation. American professor F. Ajami (1993) points at the weakness of S. Huntington's position civilizations do not control states, states control civilizations. Therefore, states and their coalitions remain the main subjects of conflicts.

The other researchers argue that today's conflicts do not stem from civilizational differences, but primarily from the structural, political, and economic inequalities of countries and regions (Hunter, S., \& O'Brien, S. 1998. 19). According to the American sociologist $\underline{Y}$. Sezgin (2000), treating the modern conflicts exclusively on the civilizational basis is not entirely true, since political and geopolitical factors are behind socio-cultural and religious causes of these conflicts.

It is obvious that the complexity and inconsistency of modern world processes cannot be described solely on the basis of the civilizational paradigm. But at the level of everyday life of people, civilizational differences are perceived as significant and defining relations between the world of Islam and the West. Moreover, in conditions of disillusionment with secular ideologies - liberalism and communism, which have deeply penetrated public consciousness since the beginning of the $20^{\text {th }}$ century, religion again becomes a significant factor in geopolitical processes. Besides, it is the religion that acts as a key marker of individuals and social-cultural identity. The revival of Islam which has a huge impact on the identity of Muslims and ensures the preservation of their traditions and identities in rapidly changing social conditions had an unexpected effect in the context of globalization.

\section{CONCLUSION}

The suggested hypothesis puts forward the influence of historical memory on the processes of integration of Muslims into the cultural and political space of European states. It is confirmed by analysis of the perception of relations between Islamic and Western civilizations their important feature being wary, and sometimes hostile attitude towards each other. This is due to the fact that historical memory, while preserving the plots of eternal rivalry and confrontation between Islamic and Western civilizations, affects the process of rapprochement, firstly, because the injuries of the past are very difficult to get used to; secondly, the memory, as a collectively lived past or as a knowledge of this past, acts as a basis of social identity. The experience of suffering is embodied in the historical memory of generations and determines their perception of the present and the future. Besides, an image of the enemy is represented and broadcasted in historical memory, embodying the collective idea of certain tragic events culprit in the fate of the people.

However, it needs to be recognized that such stereotypes of mass consciousness lay foundations for the spread, on the one hand, of Islamophobia among Europeans and, on the other, of radical Islamism in the Muslim world, which anti- 
Western ideology undermines the interaction process that has historically been present in the development of Western and Islamic civilizations.

In the search for mutual understanding between the Muslim world and the West, it should be kept in mind that the nature of their historical past was not only confrontational but also included deep civilizational interconnections, which significantly enriched them.

\section{LIMITATION AND STUDY FORWARD}

Increasing the range of individuals and nationalities surveyed can lead to increased accuracy in such a study.

\section{ACKNOWLEDGMENTS}

The article was prepared within the framework of the grant by the President of the Russian Federation for state support of young Russian scientists - Doctors of Sciences (MD - 1493.2020.6) on the topic "The Resource of Historical Memory in the System of Institutional Parameters of Social-Investment Development and Ensuring the Cultural Security of the Region".

\section{AUTHORS CONTRIBUTION}

Konstantin V. Vodenko initiated the work by proposing the framework of the study, problem statement and hypotheses. Olga S. Ivanchenko and Olesya E. Labadze performed the test hypothesis, prepared and discussed the results. Maria P. Tikhonovskova refined the methodology section and prepared the results.

\section{REFERENCES}

1. Ajami, F. (1993). The Summoning. Foreign Affairs, 72, 2-9. https://doi.org/10.2307/20045708

2. Alexander, J. C. (2004). Toward a Theory of Cultural Trauma.\| Cultural Trauma and Collective Identity. Berkeley. https://doi.org/10.1525/california/9780520235946.003.0001

3. Amur, R. (2004). Christianity and Islam: a Complicated Story. Moscow: St. Andrew's Biblical Theological Institute.

4. Assmann, J. (2011). Cultural memory and early civilization: writing, remembrance, and political imagination. Cambridge University Press. https://doi.org/10.1017/CBO9780511996306

5. Aydin, S. (2018). The emergence of Alevism as an ethno-religious identity. National Identities, 20(1), 9-29. https://doi.org/10.1080/14608944.2016.1244521

6. Bekuma, G. B., \&Bogoro, A. E. (2017). Ethno-Religious Conflicts and Democratization in Nigeria. Africa AMANI, 1 .

7. Berger, P. L., \&Luckmann, T. (1991). The social construction of reality: A treatise in the sociology of knowledge (No. 10). Penguin Uk.

8. Boykov, V.E. (2011). Historical Memory in Modern Russian Society: State and Problems of Formation. Sociologijavlasti, 5, 44-52.

9. Caruth, C. (1995). Trauma: Explorations in Memory. Baltimore: Johns Hopkins University Press.

10. Cherdymova, E.I., Afanasjeva, S.A., Parkhomenko, A.G., Ponyavina, M.B., Yulova, E.S., Nesmeianova, I.A., and Skutelnik, O.A. (2018). Student ecological consciousness as determining component of the ecologicaloriented activity. EurAsian Journal of BioSciences, 12(2), 167-174.

11. Durkheim, E. (1976). The Elementary Forms of the Religious Life. London: George Alien \& Unwin Ltd.

12. Esposito, J. L. (1999). The Islamic threat: Myth or reality?. Oxford University Press.

13. Eyerman, R. (2004) Cultural Trauma: Slavery and the Formation of African American Identity. Cultural Trauma and Collective Identity. Ed. by J. Alexander, R. Eyerman, B. Giesen, N. Smelser. Berkeley. California: University of California Press. https://doi.org/10.1525/california/9780520235946.003.0003

14. Faleeva, L.V., Bratukhina, E.V., Ezhov, S.G., Gorbunova, L.N., Lopanova, A.P., Viaznikova, L.F., and Kryukova, N.I. (2017). Student's social experience forming in university vocational training. Eurasian Journal of Analytical Chemistry, 12(7), 1127-1135. https://doi.org/10.12973/ejac.2017.00238a

15. Halbwachs, M. (1950). Collective Memory. New York: Harper and Row.

16. Huntington, S. P. (2000). The clash of civilizations? In Culture and politics (pp. 99-118). Palgrave Macmillan, New York. https://doi.org/10.1007/978-1-349-62397-6 6

17. Hunter, S., \& O'Brien, S. (1998). The future of Islam and the West: clash of civilizations or peaceful coexistence?. Greenwood Publishing Group.

18. Jung, C. (2012). The archetypes and The Collective Unconscious. Princeton: Bollingen.

19. Komar, V.I. (2004). Islam, Islamism, and Western Civilization. Afro-Asian world: Problems of Civilizational Analysis. Issue 2. Moscow: Institute of Scientific Information on Social Sciences of the Russian Academy of Sciences.

20. Leiken, R. (2011). Europe's Angry Muslims: The revolt of the second generation. Oxford University Press. https://doi.org/10.1093/acprof:osobl/9780195328974.001.0001

21. Levin, Z.I. (2017) Globalization and Nationalism, Transactions of the Institute of Oriental Studies of the Russian Academy of Sciences. Moscow: The Institute of Oriental Studies of the Russian Academy of Sciences. 
22. Lewis, B. (1993). Islam and West. Oxford: Oxford University Press.

23. Makarova, E.V., Kryukova, N.I., Sizova, Z.M., Grinenko, A.V., Erofeeva, M.A., and Bukalerova, L.A. (2019). Divergence of supreme values of the Russian world and western civilization social and philosophical analysis. EuropeanJournal of Science and Theology, 15(3), 97-107.

24. Minakhmetova, A.Z., Skutelnik, O.A., Fedorchuk, Y.M., Shulga, T.I., Pavlushin, A.A., and Shagiev, B.V. (2017). The motivational and valuable orientation of teachers as a condition to form students' tolerant behavior. Man in India, 97(3), 323-332.

25. Nnabuihe, O. E., \&Onwuzuruigbo, I. (2020). Designing disorder: spatial ordering and ethno-religious conflicts in Jos metropolis, North-Central Nigeria. Planning Perspectives, 1-19. https://doi.org/10.1080/02665433.2019.1708782

26. Romanova, K.S. (2016). Discourses of Historical Memory. DISKURS-PI, 3, 31-36.

27. Rua, O. (2017). Islam in the West or Western Islam? Breaking the Connection between Religion and Culture. Gosudarstvo, religija, cerkov'v Rossiiizarubezhom, 3(35), 77-84. https://doi.org/10.22394/2073-7203-2017-353-77-84

28. Sezgin, Y. (2000). Does Islam Pose A Threat to the West? Journal of International Affairs, 5(2), 63-76.

29. Shchedrina, O.V. (2004). Is a Multicultural Model of Migrant Integration in Russia Possible? Sociologicheskieissledovanija, 11(247), 67-74.

30. Sztompka, P. (2001). Social Change as an Injury. Sociologicheskieissledovanija, 1, 6-16.

31. Tajfel, H., and Turner, J.C. (1986). The social identity theory of inter-group behavior. In: Worchel S., Austin L.W. (Eds)/ Psychology of intergroup relations. Chicago: Nelson-Hall.

32. Toshchenko, Z. T. (2010). Historical Consciousness and Historical Memory: An Analysis of the Current Situation. Russian Studies in History, 49(1), 37-52. https://doi.org/10.2753/RSH1061-1983490103

33. Yakimova, O.A. (2011). The concept of Migrants Integration in the Context of Modern Development of Russia. Izvestija Ural'skogogosudarstvennogouniversiteta, 2(91), 53-54. 